\title{
Flashback: a Reconsideration of Austin's Performatives
}

\section{[Ohlédnutí zpět: znovuzamyšlení nad Austinovými performativy]}

\author{
Zuzana Krinkova
}

\section{DOI: 10.18355/XL.2015.08.02.2-17}

\begin{abstract}
Abstrakt
Studie navazuje na Austinovo hledání definice určující performativy, a to jednak z hlediska lingvistického, jednak z hlediska pragmatického. V první části se snažíme popsat a uchopit performativní slovesa, resp. performativní výpovědi na základě lingvistických kritérií. Zavádíme některé nové pojmy, s některými Austinovými pojmy naopak nepracujeme. Performativy považujeme za výpovědní akty, při jejichž vyslovení zároveň něco vykonáme. Nově je charakterizujeme společenskou platností (vyřčení či nevyřčení performativu je spojeno se společenskými důsledky) a konvenčně-účinkovým významem (tento význam mají ty ustálené formule, kterými je za obvyklých okolností dosaženo nějakého konkrétního účinku na adresáta). Jako primární sémantickou definici performativů jsme stanovili větu „tím, že to řeknu, to učiním nějakým nebo něčím“. Na základě tohoto schématu jsme analyzovali výpovědi, které Austin považuje za performativní. Schéma se ukázalo jako vyhovující, někdy však s nutnou mírou abstrakce a volnou aplikací. U performativních sloves jsme použili jazykově slovní rozbor, na jehož základě jsme nalezli shody s konstativními slovesy popisujícími dělání něčeho nějakým. Jako další vlastnost performativní výpovědi jsme určili její dynamický charakter (pronesení performativní výpovědi je následně doprovázeno změnou, která se projeví účinkem na adresáta). Tyto výpovědi jsme rozlišili na explicitně slovesné (tj. obsahující sloveso), implicitně slovesné (sloveso je formálně vypuštěno, slovesný význam však zůstává) a neslovesně historicky ustálené. Adresátem je v performativní výpovědi nejčastěji (pokud ne výlučně) druhá osoba či osoby, kterým je výpověd' určena, a to bud' explicitně - přímo nebo nepř́mo, nebo implicitně. Ve druhé části se zaměřujeme na pátrání po možných ,původních“ performativech a pokoušíme se stanovit jejich charakteristiku. Zaměřujeme se na dichotomii budoucnost versus performativ a dospíváme k závěru, že pomocná slovesa používaná dnes pro vyjadřování budoucnosti měla svůj prvotní, konkrétní význam. Metodou etymologického rozboru jsme dospěli k závěru, že první performativy byly spjaty s konkrétními pohybovými úkony nebo rituály nebo s mluvením obecně.

Klíčová slova

performativy, pragmatika, etymologie, filosofie jazyka, Austin, čeština, angličtina, němčina, románské jazyky, mad’arština, čínština
\end{abstract}

\section{Úvod}

Ve 20. století se v centru pozornosti filosofie ocitá jazyk jako nástroj (nejen filosofického) myšlení. John Langshaw Austin spatřoval v obratu k jazyku největší revoluci v dějinách filosofie. Od studia fungování řeči očekával i jistý výsledek pro naše poznání: díky hlubšímu uvědomění si jazyka se stane intenzivnější i naše vnímání mimojazykových jevů, které jazykem popisujeme.

Austin definuje pojem performativní výpovědi, do jejíž kategorie patří některá slova vyjadřující napřr. slib, uzavření manželství, jmenování do funkce apod. jako akt, při kterém tím, že něco sdělujeme, zároveň něco děláme. Sleduje kritéria performativní výpovědi a zavádí pojem explicitního performativu. Tato formule se podle jeho názoru zdá být produktem dlouhého vývoje. Původně mohly podobnou 
funkci plnit výpovědi dnes mnohem méně jednoznačné: např. přijdu místo slibuji, že přijdu. Performativní výpověd’ se liší od výpovědi konstativní, která může být pravdivá nebo nepravdivá. Konstativní výpověd’ Austin nazývá tvrzením. Toto je však v knize posléze zrevidováno: je nalezeno mnoho styčných bodů mezi oběma výpověd'mi, někdy i tvrzením něco děláme, např. konstatování smrti lékařem. Následně dochází k rozšiřrení teorie na obecnou: v jakém smyslu je kterákoli výpověd' zároveň děláním něčeho jiného (a ne pouhým pronášením slov). Zdařilé výpovědi musí být proneseny kompetentní osobou. Výpovědi mají různou ,ilokuční platnost": všechna slovesa vyjadřující vykonávané akty by mohla být roztř́iěna do několika skupin podle povahy těchto aktů. Austin nám nastiňuje několik etap cesty, která je stejně důležitá jako cíl, ke kterému nás má dovést. Základní teze svých myšlenek a postupný proces, jak k nim dospívá, přetváří je a doplňuje, shrnuje ve 12 přednáškách konaných na Harvardově univerzitě roku 1955.

V šedesátých, sedmdesátých a osmdesátých letech navazují na Austinovu teorii o performativech další lingvisté a filosofové, jako např. Hedenius (1963), Warnock (1973), Sadock (1974), Bach (1975), Urmson (1977), Ginet (1979), McCaughley (1979), Récanati (1980) a zejména pak John Rogers Searle (How Performatives Work, 1989), který na základě dosavadních prací shrnuje argumentaci, že performativy jsou jen výpovědi s pravdivou hodnotou (některé performativy - např. falešná varování - mohou být i nepravdivé) a nijak se tudíž neliší od konstativů. Jak dále uvidíme, Searle zásadním způsobem reviduje pohled na performativy. Otázka performativů zdaleka nezůstává bez odezvy ani v následujících devadesátých letech např. Cohen - Levesque (1990), Bach - Harnish (1992) - a pokračuje v jednadvacátém století až do současnosti - např. Kohnen (2000), Grevendorf (2002), Johansson (2003), Holtgraves (2005), Jary (2007).

Tato stat' by se dala považovat za jakýsi pozdní příspěvek k diskusi o performativech, který je založen na ryze subjektivních úvahách pisatele. Klade si za cíl znovu se ohlédnout za myšlenkami otce teorie o performativech. a se snaží znovu navázat na Austinovo hledání definice určující performativy, a to nejen z hlediska pragmatického, ale především $\mathrm{z}$ hlediska lingvistického ( $\mathrm{v}$ neposlední řadě i etymologického). V tomto ohledu se naše stat' o performativech do značné míry liší od prací výše zmíněných, v nichž se pozornost zaměřuje zejména na pragmatickou složku, byt' spojení etymologie a pragmatiky není věc nová, cf. např. Sweetser (1990). V první části se pokusíme popsat a uchopit performativní slovesa, resp. performativní výpovědi na základě lingvistických kritérií. Zavedeme některé nové pojmy, naopak s některými Austinovými pojmy nebudeme pracovat. Pokusíme se též zamyslet nad Austinovými třídami ilokučních platností. Ve druhé části se zaměříme na pátrání po možných „původních“ performativech a pokusíme se stanovit jejich charakteristiku.

Stat' se snaží uchopit podstatu performativů v co možná nejuniverzálnějším jazykovém měřítku. Definice pro performativy, resp. performativní slovesa by měla být $\mathrm{v}$ ideálním př́ípadě platná pro všechny jazyky. Z tohoto důvodu se při lingvistickém rozboru snažíme obsáhnout performativy - kromě češtiny - v co největším záběru jazyků. Zároveň se domníváme, že jazyková typologie a genealogie nehraje $\mathrm{v}$ performativních výpovědích přiliš důležitou roli.

Jsme si vědomi toho, že stávající rozsah statě zdaleka neumožňuje vyčerpání tématu. Zaměřujeme se spíše jen na některé body obsažené v Austinově díle a snažíme se na ně navázat, případně $\mathrm{k}$ nim poskytnout alternativní výklad nebo hypotézu.

\section{Co je to performativ?}

\subsection{Austinovo vymezení performativu}

Austin naznačuje v první kapitole, že existují takové výpovědní akty, které nic nepopisují, neoznamují a nekonstatují. Vyslovení takovéto věty znamená zároveň 
vykonání určitého činu nebo je jeho součástí. Tyto věty označuje jako performativní (z anglického to perform, vykonat). Mnohé performativy jsou např. výpovědní akty smluvní (sázím se) nebo deklarační (vyhlašuji válku). Jak Austin správně konstatuje, vykonání daného činu lze často uskutečnit nejen slovní výpovědí, ale i jiným způsobem.

Zároveň nesmíme opominout všechny další námitky a podmínky uvedené v první, druhé a třetí kapitole: daná formule musí být myšlena vážně ze strany všech zúčastněných, musí být vyslovena vědomě a dobrovolně oprávněnou osobou za přiměřených okolností, musí být dodrženy všechny ostatní případné náležitosti, aby došlo k uskutečnění a naplnění mluvního aktu. Austin dále rozlišuje dva prŕípady nezdaru - selhání a zneužití.

Ve snaze prvoplánově rozlišit performativní výpovědi od popisných nachází Austin rozdíl v možnosti užití prostého nebo průběhového času v angličtině: $I \mathrm{am}$ running (běžím) oproti I apologize (omlouvám se). Tento rozdíl se však posléze ukazuje jako nedostačující, navíc v mnoha jazycích je neplatný.

\subsection{Vlastnost performativní výpovědi: společenská platnost}

Všimněme si nyní i „společenské“ funkce, kterou performativní výpověd” (na rozdíl od výpovědi konstativní) zastává. Vyřčení či nevyřčení určitého performativu je totiž vždy spojeno se společenskými důsledky. Pokud totiž nějakou skutečnost pouze popisujeme, naprríklad říkáme píšu závět', výpověd' nás k ničemu nezavazuje. Pokud se v průběhu psaní rozhodneme přestat, je to jen naše rozhodnutí, z něhož pro nikoho nic neplyne. Pokud však před notářem prohlásíme odkazuji veškerý svůj majetek své neteři, naše neteř bude mít právo tento majetek vyžadovat. Některé performativní výpovědi se dokonce i „očekávaji““ a jejich nevyřčení má negativní důsledky. Př́íkladem takovéto výpovědi je například pozdrav nebo omluva, které se obecně považují za projev „slušného“ chování, ale nap̌r. i citace ve vědecké publikaci.

Performativy jsou ustálené tradicí a jsou celospolečenské. Některé z nich jsou vyžadovány za jistých okolností „explicitně“ (např. u právních aktů, citací), jiné jsou vyžadovány ,implicitně“ (např. pozdrav, poděkování, př́ípitek - pokud se neprovedou, je to považováno ,jen“ za nezdvořilé). V této stati budeme tuto vlastnost performativů nazývat společenská platnost.

\subsection{Definice performativní výpovědi: „tím, že to řeknu, to učiním nějakým nebo něčím"}

Austin se v první kapitole snaží o izolaci performativu. Výpovědní akty tohoto typu musí podle jeho názoru vyhovovat následujícím kritériím:

a) nejsou pravdivé nebo nepravdivé ${ }^{1}$,

b) vyslovení formule zároveň znamená vykonání nějakého činu nebo je jeho součástí.

Zkusme si však nyní po vzoru Austina najít svou vlastní obecnou definici performativní výpovědi. První, která nás napadá, je obecného typu: „tím, že to řeknu, to učiním nějakým nebo něčím“.

\subsubsection{Některá lingvistická kritéria konstativních sloves popisující dělání něčeho nějakým}

Při sestavení této definice jsme vyšli primárně z konstativních sloves, která popisují dělání něčeho nějakým, přetvářením něčeho v něco či stávání se něco něčím.

${ }^{1}$ Jak již bylo řečeno v úvodu, toto tvrzení v následujících letech jiní popřeli, cf. např. Searle (1989). 
Např. výrok bilim zed’ znamená „činím tuto zed’ bílou“, obohacuji si slovní zásobu znamená „činím ji bohatou“, žením se znamená „stávám se ženatým“, spřátelím se ( $s$ někým) znamená „stanu se př́itelem (někoho)“ apod.

Slovesa tohoto typu jsou vytvořena bud' z adjektiv (zde: bilý, bohatý), nebo ze substantiv (zde: žena, přitel). Máme však i mnoho sloves pocházejících ze sloves, v jejichž významové změně hrají dominantní roli pouze slovotvorné prostředky: vdávám se (tj. stávám se vdanou) má základ ve slovesu dát, opíjím se (tj. stávám se opilým) se odvíjí od slovesa pít. Tolik v češtině. Je nutné však podotknout, že podobná slovesa nacházíme $\mathrm{v}$ mnoha jiných jazycích: it. biancheggiare (it. bílit, $\mathrm{z}$ adjektiva bianco, bílý), mad'. feketítni (mad'. černit, z adjektiva fekete, černý), angl. enrich (obohatit, $\mathrm{z}$ adj. rich, bohatý), něm. befreunden (spřátelit, ze subst. Freund, př́tel), mad'. nősül (žení se, ze subst. nö, žena), mad'. barátkozni (prátelit se, ze subst. barát, př́tel), něm. betrinken (opít, ze slovesa trinken, pít). Otázku slovotvorby tu nebudeme podrobně rozebírat, stačí upozornit snad jen na to, že jednotlivé jazyky používají při tvorbě daných sloves výchozí adjektiva, substantiva a verba nestejnou měrou. Nejběžnější se zdá být tvorba $\mathrm{z}$ adjektiv, méně ze substantiv. V těchto př́padech jazyky dokáží nahradit dané sloveso slovním spojením „udělat něco nějakým či něčím“, přičemž použijí dané adjektivum, resp. substantivum: např. it. fare bianco (bílit), fare amici (spřátelit), ang. make rich (obohatit), make friends (spřátelit), něm. schwach machen (oslabit), Freunde machen (spřátelit), mad'. feketének csinálni (začernit), barátokat csinálni (spřátelit). U některých jazyků je tato analytická forma stejně běžná nebo i běžnější, v závislosti na převažujícím jazykovém typu. Tato slovesa ze zároveň dají analyticky a či synteticky změnit z ,udělat nějakým“" na „stát se nějakým“: it. diventare bianco (zbělet), diventare amici (sprátelit se), ang. become rich (zbohatnout), become friends (sprátelit se), něm. schwach werden (oslabit se), befreunden sich, Freunde werden (spř́telit se), mad'. feketülni, feketévé lenni (černat), barátkozni, barátokká lenni (spřátelit se), opět v závislosi na jazykovém typu. Slovesa odvozená ze sloves (např. opít) se dají rovněž vyjádřit opisně - slovesem učinit (resp. stát se) a slovesným adjektivem daného verba, v některých jazycích příčestím: česky: opit - učinit opilým, opit se - stát se opilým; něm. betrinken - betrunken machen (opít), betrinken sich - betrunken werden (opít $\mathrm{se}$ ), ang. (v tomto prípadě pouze analytické tvary) make drunk (opít), get drunk (opít se).

\subsubsection{Aplikace naší definice na některé výpovědi označené Austinem za performativní}

Podívejme se nyní, do jaké míry lze tyto poznatky aplikovat na performativní výpovědi. Zkusme nejprve náhodně vybrat několik performativních vět, které uvádí Austin, a ukázat na nich naši definici.

1) Vyslovením slova ano při svatebním obřadu učiníme dotyčný protějšek svým zákonným partnerem.

2) Kapitán pronese křtím tuto lod' jménem... a spolu s roztř́šštěnou lahví učiní onu lod' pokřtěnou, tj. pojmenovanou tak a tak.

3) V závěti napsaným odkazuji svůj dům své dceři učiníme onen dům jejím.

4) Formulí sázím se s tebou o tisic korun učiníme oněch tisíc korun (na obou stranách) předmětem sázky a tudíž hypoteticky již ne výlučně naším či cizím vlastnictvím.

5) Soudce při verdiktu nevinen učiní obžalovaného osvobozeným.

6) Rozhodčí při verdiktu aut učiní zásah neplatným.

7) Vyslovením šach (ovšem samozřejmě spolu sodpovídajícím postavením figurek) učiníme partii ukončenou.

8) Formulí vyhlašuji válku učiníme válku zahájenou.

9) Formulí slibuji, že tam budu učiním svou přítomnost tam jistou.

5

XLinguae Journal, Volume 8 Issue 2, April 2015, ISSN 1337-8384 
10) Formulí omlouvám se kvalifikuji svůj předchozí čin jako chybný, distancuji se od něj a žádám, aby to okolí vzalo na vědomí. Zároveň se čin stává omluveným.

Na první pohled je tu patrných několik rozdílů, a to sice:

a) zdá se, že performativy nejsou vázány nutně na slovesa, performativní výpovědi mohou být neslovesné (není tu však přesto přítomen slovesný význam výpovědi? $\mathrm{k}$ tomuto bodu se ještě vrátíme);

b) zatímco předchozí konstativní slovesa byla úzce spojena pouze s daným procesem, performativní výpovědi jsou, jak již ostatně zdůraznil Austin, doplňující součástí $\mathrm{k}$ dalším úkonům odehrávajícím se ve specifických a jasně vymezitelných situacích;

c) a konečně třetí rozdíl: převod performativních výpovědí na konstrukci „tím, že něco řeknu, učiním něco nějakým" není tak jednoznačně daný a jednoduchý jako převod předcházejících sloves na analytické konstrukce. Odmyslíme-li si však tyto obtíže, v zásadě možný je. Rovněž je možný hypotetický převod na konstrukci „tím, že něco řeknu, stane se to nějakým“, ve skutečnosti však pro nás nemá žádný význam, formule zůstává beze změny: křtím tuto lod'...tj. činím ji pokřtěnou, lod' se zároveň i stává pokřtěnou.

\subsubsection{Vyhodnocení zástupců Austinových pěti tř́id ilokuční platnosti, zda odpovídají našim výše uvedeným kritériím}

Podívejme se nyní na některá slovesa, která spadají do pěti tříd ilokuční platnosti, tak jak je definuje Austin, a zhodnot'me je podle předcházejících kritérií. Ze skupin verdiktiv nám bude za vzorek sloužit sloveso zproštovat a oceňovat, $\mathrm{z}$ exercitivů odvolat a omilostnit, $\mathrm{z}$ komisivů slibovat, zavázat se a prísahat, $\mathrm{z}$ behavitivů želet, žehnat a zatracovat a konečně $\mathrm{z}$ expozitivů např. tvrdit a poznamenat.

Začneme verdiktivy. Výrok vyřčený soudcem zproštuji vás viny znamená de facto „činím vás viny prostým“, tj. nevinným. Původním adjektivem je zde prostý. Výrok má za následek osvobození obžalovaného a je respektován okolím, má tedy společenskou platnost.

Odhadcův výrok oceňuji tuto nemovitost na milión korun znamená, že nemovitost nabývá (hypotetické, výchozí) ceny miliónu korun, odhadce tudíž učinil nemovitost oceněnou (a zároveň je tato cena východiskem např̀. pro další jednání). Původním substantivem je cena. I zde má výrok společenskou platnost.

Rovněž exercitivní výrok odvolávám vás z funkce, je-li pronesen osobou $\mathrm{k}$ tomu zmocněnou, má společenskou platnost: ve funkci již nejste, činím vás z funkce odvolaným. Původním slovesem je volat, zde však již v přeneseném smyslu. Podobně např. zbavuji vás svéprávnosti znamená ,činím vás nesvéprávným“ (zbavit pochází ze slovesa být, doslova by se tedy výrok dal chápat jako „činím, že již nejste svéprávnýc“) či sesazuji vás z úr̆adu je „činím vás sesazeným“" (sesadit pochází evidentně ze slovesa sedět, sedělo se např. na trůně či na stolici, dnes je rovněž již chápáno v přeneseném smyslu). Omilostnit pochází ze substantiva milost a jeho záměr je jasný: dát někomu milost znamená učinit ho propuštěným, volným.

Podívejme se nyní na komisivy. Výrokem slibuji v podstatě ř́káme, že činíme nějaký náš budoucí akt jistým. Slibovat nemá na první pohled jednoznačnou etymologii, má však souvislost $\mathrm{s}$ adjektivem libý a jistou významovou spojitost se slovy líbit se, libat, jakož i německým lieb a latinským libet. Důležité by mohlo být to, že se jedná o slib vztahující se vždy do budoucna. Může mít snad souvislost s chtěním něčeho (chceme to, co se nám líbí).

Sloveso zavazovat se má jasnou souvislost se slovesem vázat a je používáno v přeneseném významu. Akt se činí závazným, obligatorním. Sloveso př́isahat je jasným důkazem starého performativního významu, kdy formule doprovázela sahání 
na meč, křiž apod. Př́isahou činíme nějaký akt pravdivý, skutečný. Všechna výše uvedená slovesa mají společenskou platnost.

Behavitivní sloveso želet ve výroku želím toho pochází ze substantiva žal. Pokud něčeho želíme, říkáme, že něco kvalifikujeme jako politováníhodné (viz též výrok lituji toho - základem tohoto slova je rovněž ,žal“, v češtině lítost, ve španělštině a italštině luto, žal). Je otázka, zda a co při tomto výroku zároveň činíme. Platnost těchto sloves může být rovněž společenská, vyjádření lítosti či žalu se v některých situacích skutečně „vyžaduje“ (např. na pohřbu či pokud je formule použita ve smyslu omluvy).

Naproti tomu se slovesem žehnat problém není: žehnáním něco učiníme požehnaným a nijak nás to nezaráží. Performativní význam tohoto slovesa je rovněž starý: sloveso se k nám dostalo přes němčinu (segnen) a má původ v latinském signare, tj. znamenat (kř́žem), to z lat. signum (znamení). Původně se tedy opět jednalo o sloveso odvozené ze substantiva.

Sloveso zatracovat, tj. činit něco zatraceným, pochází ze slovesa ztratit. Jedná se pravděpodobně o ztrátu někde v záhrobí (srovnejme se slovem zpropadený, tj. propadlý do pekla a formulí at' se propadnu, jestli...). Tato slovesa rovněž mají (nebo spíše v minulosti měla) společenskou platnost.

Poslední skupinou jsou expozitivy. Výrokem tvrdím, že však nic nečiníme tvrdým (ač sloveso z tohoto adjektiva nepochybně pochází), nýbrž jím pokládáme svůj názor za pevný a „utvrzujeme“ v tom sebe i okolí.

Sloveso poznamenat pochází nejspíše ze substantiva znameni (poznamenaný je někdo, kdo nese nějaké znamení). Navzdory tomu se však toto sloveso nepoužívá jen ve svém původním významu „označit“, ale i ve významu něco „zmínit“ a právě v tomto druhém významu ho Austin řadí mezi expozitivy.

U výše uvedených expozitivů se však zdá být poněkud problematická jejich společenská platnost. Co se stane, pokud něco tvrdíme nebo poznamenáme?

Zatímco u všech předchozích sloves jsme zaznamenali performativní význam, který byl patrný v běžném kontextu na první pohled, poslední dvě zmíněná slovesa dávají najevo spíše osobní postoj mluvčího. Na rozdíl od ostatních sloves jsou také výrazně více vázána na kontext (domníváme se navíc, že v běžném kontextu jejich performativní význam často zcela chybí) a zpravidla musí být rozvinuté do vět („tvrdím, že..."). Za určitých okolností se mohou však expozitivy performativními slovesy stát: jako prŕíklad uved'me, že vyjádření nesouhlasu či námitky při právu veta způsobí, že akt, který měl proběhnout, neproběhne.

\subsection{Slovesný/dynamický charakter performativních výpovědí a úkony s nimi spojené}

Performativy však zdaleka nejsou omezeny pouze na slovesa. Ta sice tvoří většinou ,jádro“ výpovědi (pojem ,jádro“ je zde míněn pouze obrazně, nechápejme ho lingvisticky!), nicméně často k performativnímu účinku nestačí. Užívejme proto od této chvíle raději termín performativní výpověd’.

$\mathrm{Na}$ základě Austinových i našich kritérií dospíváme k názoru, že performativní výpovědi jsou slovesného charakteru. Nejsou totiž statická, naopak souvisejí se změnou stavu.

Jak jsme však již naznačili, performativní výpověd' nemusí nutně obsahovat slovesa, i neslovesné výpovědi mohou být performativní.

Jako příklad nám poslouží pozdrav dobrý den a přípitek na zdraví. Obě výpovědi jsou ustálenými formulemi, které jsou společensky „vyžadované“. Námitka, že jejich vyslovením se vlastně nic nevykoná, je sice možná, na druhou stranu však výpovědi mají společenskou platnost $\mathrm{v}$ tom smyslu, že pokud je neřekneme, snadno někoho urazíme. Tím, že je vyslovíme, dáme najevo svůj kladný vztah k osobě, jíž je výpověd' adresována. 
A nyní ke zdánlivě chybějícím slovesům v obou výpovědích. Předně se obě výpovědi dají nahradit slovesnými při zachování stejného významu: zdravím vás a pripijím vám (na zdraví). Zdánlivě neslovesné výpovědi v sobě implikují nevyjádřený verbální element: preji dobrý den, prííjím vám (nebo pijme) na zdraví. Obdobnou výpovědní hodnotu nají i další přání: dobrou chut', tedy vlastně preji dobrou chut', se dá vyjádřit ve většině jazykủ i vazbou at' ti chutná nebo nech si chutnat. Zajímavé je, že naprŕíklad v mad'arštině se dodnes považuje za zdvořilejší formule se slovesem: jó napot kívánok (dobrý den přeji). Naopak pouhé jó napot (dobrý den) vyznívá poněkud nedbale, zdravenému se tím neprokazuje náležitá úcta.

Jak však budeme nazírat na pozdravy typu servus či pozdrav pánbi̊h či čínský pozdrav nín hăo („,dobrý den“, doslova „vy jste dobrýc)? Že i tyto výpovědi jsou performativní, o tom svědčí podle našich kritérií stanovená jejich společenská platnost. Naše definice však na ně lze aplikovat jen velice volně a to pouze ze sémanticko-pragmativního hlediska: „tím, že jsem danou formuli ř́íkám, zdravím vás“. Jedná se spíše o jakési ustálené formule s performativním významem, než o samotné performativy. Otázkou však je, zda a do jak míry je nutné a vhodné mezi nimi rozlišovat.

Vrat'me se ještě na okamžik k pronesení přípitku. Ten je totiž, na rozdíl od přání dobrého dne a dobré chuti, nutně a vždy svázán ještě s dalšími úkony, totiž pozvednutí daného poháru (př́ípadně i přituknutím) a následným napitím se. (U přání dobrého dne není kývnutí, úklona či podání ruky povinné, dobrou chut můžeme popřát i někomu během jeho jídla.)

Zdá se, že právě oblíbenost alkoholického opojení způsobila u mnoha národů existenci velkého množství různých typů př́ípitků, př́ípadně i pijáckých výkřiků. V zásadě se připíjí na zdraví někoho (vždy však druhé osoby, prŕípadně na zdraví všech zúčastněných ${ }^{1}$ ) a na úspěch. Jedná se tudíž vlastně o jakousi „magickou“ formuli přání dobrého spojenou s rituálem pití (alkoholu).

Robert Wace ${ }^{2}$ žijící ve 12 . století popisuje ve svém díle Roman de Rou (napsaném normanskou francouzštinou) rozdílné chování Anglosasů a Normanů v předvečer bitvy u Hastingsu (1066). Zatímco Normané a Francouzi strávili noc v modlitbách, Angličané jedli a pili dlouho do noci a vůbec nešli spát:

„Beo bliðe" křičeli a ,wes hoel"

$a$,lcet hit cuman " a ,drencia hoel",

„drinc hinderweard" a ,drinc to me“,

,,drinc healf" a, drinc tome ". 3

Všechny uvedené výrazy, u tehdejších Anglosasů již ustálené formule, doprovázené náležitými úkony, se dají považovat za performativy.

${ }^{1}$ Cf. např. mad'. přípitek egészségedre „na tvé zdravi“, egészségetekre „na vaše zdravi" a pod.

${ }^{2}$ Robert Wace, Norman z Jersey, byl králem Jindřichem II. v 60. letech 12. století pověřen sepsat oslavné dějiny Normanů, pojmenované podle praotce Rolla (tj. Rou). Jednalo se o paralelu s jeho dřívějším dílem Roman de Brut, věnovaným Británii před Normany.

${ }^{3}$ Staroanglické výrazy „bud' št'asten“, „zůstaň zdráv“, ,at’ sem přijde“ (tj. společný pohár), ,pij hltavě“, ,pij pozpátku“, ,„připij mi““, „vypij půl“, ,zpij se“. Všechno jsou to staroanglické př́ípitky a pijácké výkřiky, které Anglosasové pořvávali v noci před rozhodující bitvou u Hastingsu. Geoffrey z Monmouthu, píšící kolem roku 1140, uvádí: „do dnešních dnů přetrval v Británii obyčej připíjet na hostině tomu, který přebírá pohár, 'waesseil' a ten odpovídá 'drincheil'.“ Cf. Ostler (2007: 489-490). 
Charakter performativních výpovědí je zcela nepochybně dynamický. Performativní výpověd' je bud' explicitně slovesná, tj. obsahuje sloveso, at' už performativní či ne, nebo implicitně slovesná, tj. sloveso bylo z ustálené formule již vypuštěno, nicméně jeho význam je $\mathrm{v}$ ní zachován. Některé pragmatické formule jsou však i zcela neslovesné, tj. jejich původní sloveso se $\mathrm{z}$ výpovědi beze stopy vytratilo již v minulosti a v současné době není možné ho ve výpovědi identifikovat. V těchto výpovědích mnohdy totiž ani nebylo - performativní výpověd' se tu zpravidla váže $\mathrm{k}$ nějaké tradicí ustálené události, která se však již vytratila z povědomí dnešních mluvčích. Tyto formule budeme pracovně nazývat jako neslovesně historicky ustálené (tento pojem není však zcela vyhovující, nebot' všechny performativní výpovědi jsou vlastně formule historicky ustálené).

Každá performativní výpověd' má tudíž dle našeho názoru charakter bud' slovesný (explicitně nebo implicitně) nebo alespoň slovesný z čistě pragmatického hlediska. Možná se však $\mathrm{v}$ tomto případě může pojem slovesný zdát nevhodný. $\mathrm{Z}$ tohoto pohledu je tedy lépe než o slovesném charakteru hovořit o dynamickém charakteru performativní výpovědi. Tento charakter se zjednodušeně pozná tak, že pokud danou formuli proneseme (za náležitých okolností), něco se vždy „změní“. Je však třeba uvažovat v abstraktním smyslu a s ohledem na kontext. Sloveso zdravím ve větě každé ráno zdravím sousedy rozhodně není performativní a performativní není ani celá výpověd'. Oproti tomu zdravím tě je performativní: v daném okamžiku jsme totiž učinili danou osobu pozdravenou a tím došlo i ke změně (navázání kontaktu).

\subsection{Austinovy lokuční, ilokuční a perlokuční akty}

Počínaje osmou přednáškou začíná Austin pracovat s pojmy lokuční, ilokuční a perlokuční akty, které podle jeho názoru přesněji vystihují danou problematiku prŕliš obecného vymezení performativu. Podívejme se nejprve na jeho teze.

Austin prohlašuje, že akt „,̌́íkání něčeho“ je performací lokučního aktu. Dle jeho názoru, když něco říkáme, uskutečňujeme lokuční akt, který je zhruba ekvivalentní tomu, pronese-li se určitá věta s určitým smyslem a určitou referencí, což je ekvivalentní „významu“ v tradičním smyslu slova. Mezi akty ilokuční patří např. informování, přikazování, varování, zavazování se k něčemu: výpovědi mají jistou konvencionální platnost. Akty perlokuční jsou akty, které přivodíme nebo uskutečníme tím, že něco řekneme, např. přesvědčování, přemlouvání, odstrašování, vyvolávání, překvapení či uvádění v omyl. Ilokuční akt musíme odlišit od aktu perlokučního: když jsem to ř́kal, varoval jsem ho oproti tím, že jsem to řekl, jsem ho přesvědčil, prekekapil, přiměl $k$....

Pojmem ilokuce není reference $\mathrm{k}$ důsledkům lokuce, nýbrž ke konvenčním ilokučním platnostem, které se týkají specifických okolností daného výpovědního aktu. Ilokuční akt není tedy důsledkem aktu lokučního.

Ilokuční akt je však spojen s vyvoláním účinků (pokud ne, tak akt není zdařilý), je dosaženo pochopení významu a platnosti lokuce, porozumění. Mnoho ilokučních aktů vybízí díky konvenci k odpovědi nebo k následné sekvenci (uposlechnutí rozkazu, dodržení slibu).

Rozlišení mezi přikázal jsem mu a on uposlechl a přiměl jsem ho, aby uposlechl spočívá $\mathrm{v}$ tom, že ve druhém př́ípadě bylo použito ještě dodatečných prostř̌edků. Perlokuční akt je dosažením určitého perlokučního cíle nebo vyvolání určité následné perlokuční sekvence. Určité perlokuční akty vedou vždy k vyvolání sekvencí, zejména akty, u nichž neexistuje žádná ilokuční formule (určitou lokucí můžeme překvapit, i když neexistuje formule překvapuji vás.

Pro perlokuční akty je charakteristické, že odpovědi nebo sekvence lze dosáhnout i nelokučními prostředky (např. namířením pistole), ovšem můžeme např. varovat či přikázat bez verbálních prostředků, a přesto jde o ilokuční akty. 
Ilokuční akt nemůže existovat, pokud použité prostředky (i ty neverbální) nejsou konvencionální. Mnoho ilokučních aktů však nemůže být uskutečněno jinak, než že se něco řekne (konstatování, informování, argument, posuzování, vystavení odhadu a nálezu - v právním smyslu, většina verdiktivů, expositivů).

Vždy však záleží na kontextu a účelu dané výpovědi. Rozdíl mezi konstativní a performativní výpovědí spatřuje Austin v tom, že u konstativní výpovědi abstrahujeme od ilokučních aspektů řečového aktu a soustřed'ujeme se na aspekt lokuční. U performativní výpovědi se zaměřujeme co možná nejvíce na ilokuční platnost výpovědi a abstrahujeme od oné dimenze, kterou představuje korespondence $\mathrm{s}$ fakty. Musíme tudíž rozlišit mezi lokučními a ilokučními akty a kriticky u každého druhu ilokučního aktu (varování, odhady, verdikty...) zvážit jeho ilokuční platnost.

V poslední kapitole Austin shrnuje své dosavadní poznání a vytváří seznam pěti tříd ilokučních platností výpovědního aktu:

1) Verdiktivy - je vynášen určitý verdikt; učiní se rozhodnutí o něčem (faktu nebo hodnotě), o čem dosáhnout jistoty je z různých důvodů obtížné (napřr. rozsudek, odhadnutí, ocenění, ohodnocení).

2) Exercitivy - uplatňuje se moc, právo nebo vliv (jmenování do funkce, hlasování, nařizování, vybízení, udílení rady, varování....).

3) Komisivy - dávání slibů nebo jiné přebírání závazků, zavazuje k určitému počínání, také deklarování nebo oznamování záměru, zaujímání stanoviska. Existuje určité spojení mezi komisivy na jedné straně a verdiktivy a exercitivy na druhé straně.

4) Behavitivy - nesourodá třída, do níž spadají postoje a sociální chování (omluvy, blahopřání, doporučení, kondolování, proklínání, vyzývání).

5) Expozitivy - objasňují, jak se naše výpovědi vřazují do debaty nebo konverzace, jaký výklad slovům přísluší.

Závěrem Austin prohlašuje, že jeho rozdělení není definitivní a že bude muset být ještě podrobeno dalšímu zkoumání.

Austin se snaží o klasifikaci všech výpovědí, které se zdají být performativní (dle jeho počáteční definice). Domníváme se, že takováto klasifikace je jistě zajímavá z hlediska snahy o širší uchopení a podrobnější zkoumání různých druhů (nebo spíše účinků) performativu, nicméně pro naši potřebu - tj. primárního určení, zda daná výpověd’ je či není (nějakým způsobem) performativní, je zcela nadbytečná a tř́šstí naši pozornost.

Performativní výpovědi se dají na základě jejich vnějšího popisu rozdělit na explicitně slovesné, implicitně slovesné a neslovesně historicky ustálené. Všechny tyto výpovědi mají však dynamický charakter, který způsobuje nějakou změnu (nějaký účinek a nějaký důsledek).

Avšak pozor: ne všechny účinky jsou nutně vyvolány performativními větami. Někoho se můžeme dotknout či urazit ho tím, že např. nepozdravíme. Toto je účinek absence performativní výpovědi, která má, jak jsme uvedli, společenskou platnost. Někoho se však můžeme dotknout i tak, že ho zkritizujeme, zesměšníme, opomineme apod., aniž bychom použili nějakou performativní formuli. Pokud v tomto prŕípadě nebyl účinek naším záměrem, jedná se o nedorozumění. Pokud jsme však účinek zamýšleli našimi slovy vyvolat, nejedná se rovněž o performativní výpověd' $\mathrm{v}$ jakémsi abstraktním smyslu, z ryze pragmatického hlediska? Lze vůbec tedy stanovit existenci nějakých performativních výpovědí? Nemohou být za určitých okolností vlastně všechny výpovědi (či dokonce jejich absence) performativní?

V jistém smyslu by se dalo uvažovat o jakémsi pragmaticky teoretickém rámci, do kterého by mohly za určitých okolností spadat všechny takové výpovědi, jejichž vyslovením je dosaženo nějakého konkrétního účinku na adresáta. 
Nicméně oporou pro existenci performativních výpovědí nám může být jeden zásadní rozdíl, který spočívá v poněkud vágní definici „obvyklých okolnosti““. Ustálené performativní výpovědi totiž za obvyklých okolností svůj účinek mají - což souvisí i s jejich námi dřive definovanou společenskou platností. Naproti tomu jiné věty, které nejsou performativní, tento účinek primárně nemají a nabývají ho pouze za specifických okolností. I když je toto vysvětlení zjevně nedostačující, domníváme se, že velkou roli tu skutečně hraje tento pragmatický význam výpovědí. Nazvěme ho třeba významem konvenčně-účinkový, termínem, který se zdá být vyhovující vzhledem našemu již zavedenému termínu společenské platnosti. Prvotní význam pragmatických výpovědí je tedy konvenčně-účinkový.

\subsection{Adresát u performativních výpovědí}

Výpověd' zpravidla není pronesena tehdy, pokud nemá žádného adresáta. Je možné performativní výpověd' vymezit i z tohoto hlediska?

Performativní výpověd' je zpravidla přímo určena jednomu či více adresátům. Na rozdíl od jiných výpovědí je však adresát ponejvíce ve 2. osobě jednotného či množného čísla. Performativ, jímž se mluvčí obrací sám k sobě, se zdá být nepravděpodobný, ne-li nemožný. Performativní výpověd' nejčastěji adresujeme prímo. $\mathrm{V}$ tomto rozlišení tkví dle našeho názoru rozdíl mezi výpovědí zdravím tě a zdravím ho - v prvním př́ípadě se jedná o performativní výpověd', ve druhém o konstativní. Performativní výpověd' typu křtím tuto lod'jménem xy není adresovaná lodi, nýbrž všem, pro které je tato informace relevantní.

Performativní výpověd' však může být adresována i nepřímo: odkazuji svioj dům své dceři je za přiměřených okolností výpovědí performativní, s pragmatickým významem stejným jako u výpovědi dcero, odkazuji ti svůj dům.

Adresát je v performativní výpovědi zastoupen tudíž vždy, a to sice bud' explicitně a př́mo - nejčastěji zájmeny ty nebo vy (odkazuji ti svưj dům) - nebo explicitně a nepřímo - v tomto príípadě se hovoří o třetí osobě či osobách, kterým je určeno sdělení (odkazuji dům své dceři), sdělení samo však může být proneseno k jiné osobě (např. notáři). Může však být zastoupen i implicitně, kdy se neuvádí žádná osoba, které je sdělení adresováno, ale z kontextu tato osoba vyplývá. Toto je př́ípad výroku křtím tuto lod' jménem xy (adresováno všem zúčastněným a též ostatní, kteří budou mít s lodí něco společného), dále u pozdravů (dobrý den) a přípitků (na zdravi), kdy je adresátem osoba, na kterou se obracíme.

Výše naznačené definice se zdají být platné, otázkou však zůstává, zda a do jaké míry jsou platné pouze pro výpovědi performativní nebo pro všechny výpovědi.

\subsection{Závěr k první části}

Shrňme nyní stručně naše dosavadní zjištění obsažená v této kapitole do několika vět:

1) Performativy jsou výpovědní akty, při jejichž vyslovení zároveň něco vykonáme. Jsou charakterizovány společenskou platností a konvenčně-účinkovým významem.

2) Sémantickým vzorcem jsme určili definici „tím, že to řeknu, to učiním nějakým nebo něčím“. Toto schéma se ukázalo jako v zásadě platné, v mnoha př́ípadech však byla nutná abstrakce a volná aplikace.

3) U performativních sloves jsme použili jazykově slovní rozbor, na jehož základě jsme nalezly shody s konstativními slovesy popisujícími dělání něčeho nějakým.

4) Performativní výpovědi jsou dynamického charakteru. Rozlišili jsme je na explicitně slovesné, implicitně slovesné a neslovesně historicky ustálené.

5) Adresátem je v performativní výpovědi nejčastěji (pokud ne výlučně) druhá osoba či osoby, kterým je výpověd' určena, a to bud' explicitně - přímo nebo nepřímo, nebo implicitně. 


\section{Hledání původních performativů}

\subsection{Budoucnost versus performativ?}

V šesté kapitole se zamýšlí Austin nad relativní novostí explicitních performativů: „(...) můžeme vyslovit tuto hypotézu: historicky vzato se z hlediska vývoje jazyka musel objevit explicitní performativ později než některé primárnější výpovědi, z nichž mnohé jsou již přinejmenším implicitními performativy, které jsou do většiny nebo mnoha explicitních performativů zahrnuty jako části určitého celku $(\ldots)^{\text {“1 }}$ Austin tu upozorñuje na rozdíl vět typu učiním to a slibuji, že to učiním, případně budu tam a slibuji, že tam budu. Věty prvního typu pak považuje za původnější, tedy starší, zatímco věty obsahující explicitní performativy se pravděpodobně vyvinuly později, tak jak to rozvíjející se a vyspělejší společnost vyžadovala. Austin zde vyslovuje hypotézu, že „v primitivních jazycích nebylo ještě možné jasně rozlišit, která z těchto jednání, jež můžeme vykonat, vykonána skutečně byla (...). V jednoslovných primitivních jazycích se mohlo např. slovem býk nebo hrom varovat, informovat, předpovídat atd.“2

Hypotéza o primitivních jednoslovných jazycích se zdá být správná. Podívejme se však na věty typu budu tam a slibuji, že tam budu z trochu jiného pohledu.

Vyjadřování budoucnosti má v každém jazyce poněkud specifické postavení. Moderní jazyky mají zpravidla více možností, jak vyjádřit budoucnost a některé mohou rozlišovat i budoucnost blízkou a vzdálenější. V žádném jazyce však nemá budoucnost původní tvar. ${ }^{3}$

Pokud zde namátkou srovnáme několik současných, indoevropských i neindoevropských jazyků různého jazykového typu (flexivní, aglutinační, izolační), dospějeme $\mathrm{k}$ závěru, že budoucí čas se musel být chápán jako jakýsi pomocný čas a původně mohl mít možná význam jiný než temporální. Tuto hypotézu se pokusme dokázat na následujících př́íkladech.

V angličtině se pro vyjádření budoucnosti používá sloveso will. Toto slovo ve svém původním (i dnešním samostatném) významu znamená „vůle, úmysl, ochota, chtění, rozhodnutí" a v tomto významu se objevuje i v jiných indoevropských jazycích, např. v němčině v podobě wollen: ich will (já chci), v italštině volere (chtít), ale i v češtině ve slově vůle.

Význam vůle či chtění pro vyjádření budoucnosti není zdaleka ojedinělý, použivá se ho například i některých př́padech v čínštině yào je ukazatel budoucnosti (přičemž wŏ yào, ,já chci“). Pokud tedy něco chceme, znamená to i to, že to s největší pravděpodobností i uděláme. Rovněž v hovorových variantách různých dalších jazyků jsou si často vůle, chtění a budoucnost velmi blízké, např. v italštině sloveso volere (chtít): che vogliamo fare? (co uděláme?, dosl. co chceme dělat?)

V němčině se používá sloveso werden, tedy ,stávat se, nastávat, vzniknout“: ich werde rot (rudnu) oproti ich werde dort sein (budu tam). Tato koncepce tedy nahlíží na budoucnost nikoli jako na chtění něco udělat, na něco vůlí ovlivnitelné, nýbrž jako na jakýsi samovolný proces vznikání, nastávání něčeho.

V mad'arštině se pro vyjádření budoucnosti použivá sloveso fog. I toto sloveso má svůj další význam, a to sice „uchopit, chopit se, chytit, držet“, používaný často s předponami, které ho vidově, ale i sémanticky modifikují: megfogom a kezét (chytnu ho za ruku) oproti ezt fogom csinálni (to budu dělat). Toto pojetí budoucnosti je rovněž zajímavé: pokud něco chytnu a udržím to, mohu s tím počítat, je to to, co

\footnotetext{
${ }^{1}$ Austin (2000: 80).

${ }^{2}$ Ibid., 80.

${ }^{3}$ Cf. Flusser (2005: 64-72).
} 
„bude“. Pro původně kočovný mad’arský národ jistě důležitá součást přežití, z hlediska pojednání o performativech však i neméně zajímavý postřeh: něco slíbit vyžaduje zároveň také to i dodržet.

Jisté zdánlivé obtíže však nastávají při vhledu do vyjadřování budoucnosti ve slovanských a románských jazycích. Ve slovanských jazycích vyjadřujeme budoucnost - pokud ponecháme stranou rozličné předpony - pomocí slovesa být. Takto ji vyjadřovala i latina, z níž vzešly dnešní románské jazyky. Zdá se, že sloveso být je tu pravým pomocným slovesem, které skutečně nemá jiný než časový význam. Vyjadřování budoucnosti v těchto jazycích mohlo být tudíž mladšího data a vzniknout až s větším rozvinutím jazykové struktury.

Blízká budoucnost je naproti tomu v jazycích, které ji vyjadřují, spojena vždy s pohybem v prostoru: anglicky I am going to write it (doslova: jdu to napsat), španělsky voy a hacerlo (doslova: jdu to udělat). Zdá se, že sloveso jít má schopnost vyjádřit blízkou budoucnost ve všech jazycích, i v těch, v nichž se s touto gramatickou kategorií nepočítá: řekneme-li česky jdu to napsat, nemusí to nutně znamenat, že se opravdu někam přemístíme. Tím, že někam jdeme, můžeme však zároveň počítat i s tím, že někam dojdeme, proces se tudíž posune dále. Avšak pozor: do značné míry se totiž $\mathrm{v}$ některých jazycích překrývá i vyjádření blízké budoucnosti a vůlí něco udělat. Anglická věta If I want to catch the train, I'll have to leave now (pokud chci stihnout vlak, budu muset odejít ted') se dá ríci i takto: If I am going to catch the train, I'll have to leave now. Významy jsou si ekvivalentní.

Vrat'me se nyní k performativům a $\mathrm{k}$ Austinově hypotéze. Větu slibuji, že tam budu přeložme do angličtiny: I promise (that) I will be there, do němčiny: Ich verspreche, dass ich dort sein werde. Do mad'arštiny přeložme větu slibuji, že to budu dělat: Megígérem, hogy ezt fogom csinálni. ${ }^{1}$ Nyní přeložme věty doslovně na základě výše uvedené analýzy. Anglická věta by se dala chápat takto: „slibuji, že tam chci být“. Německá věta představuje větší obtíže, v zásadě se nám však nabízí tato interpretace: „slibuji, že se stávám tam jsoucím“, popř. „slibuji, že nastává mé bytí tam“. A konečně mad'arská věta: „slibuji, že se chytám/chápu dělání toho“. V tomto kontextu se zdá, že použití performativního slovesa slibuji je nevhodné: spojení „slibuji, že chci“ či „slibuji, že se stávám“ nedává smysl a ani „slibuji, že se chytám“ nezní prŕíliš přesvědčivě. Co se však stane, když naše „budoucnostní“ slovesa převedeme (třeba i pomocí dokonavého vidu) do budoucnosti? Anglická věta bude mít význam „slibuji, že to budu chtít udělat“, německá věta „slibuji, že nastane mé bytí tam“ a mad'arská věta „slibuji, že se chopím dělání toho“. Věty jsou nyní pochopitelnější, performativním slovesem slibovat se totiž dá odkazovat pouze do budoucnosti.

Pomocná slovesa pro vyjadřování budoucnosti již evidentně ztratila svůj původní význam. Kdysi ho však pravděpodobně v sobě nesla a to je třeba mít na zřeteli při odkrývání složité struktury současného jazyka. Pokud Austin zastává názor, že ,explicitní rozlišení různých platností, které taková výpověd’ může mít, je pozdější a závažnou realizací jazyka“"2 , a že „primitivní nebo primární formy výpovědi si v tomto ohledu zachovávají dvojakost nebo dvojznačnost (...)“ a ,jazyk jako takový ve svých primitivních stadiích není přesný، ${ }^{3}$, je třeba upozornit na to, že různé jazykové platnosti mohly mít jinou podobu než dnes. Místo abstraktního slibuji pro

${ }^{1} \mathrm{~V}$ mad'arštině ve tvoření budoucího času od slovesa být existuje výjimka: místo tvaru fogok lenni se používá jednoslovné leszek. Kvůli názornosti jsme proto zvolili pozměněný př́klad.

${ }^{2}$ Austin (2000: 81).

${ }^{3}$ Ibid., s. 81 .

13

XLinguae Journal, Volume 8 Issue 2, April 2015, ISSN 1337-8384 
vyjádření vůle něco učinit mohlo stejně dobře sloužit i konkrétnější chci jako popis vnitřní intence či stávám se, chápu se/ chytám se jako popis vnějšího stavu či činnosti. Jednalo by se i za těchto podmínek o implicitní performativy?

Jak jsme uvedli, sloveso slibovat odkazuje pouze k budoucím dějům. Pro vyjádření dějů přítomných bychom jej mohli nahradit jiným performativním slovesem, a to sice prísahat. Toto sloveso je schopné účinně působit ve všech časových rovinách, např. př́sahám, že nemám milence; př́sahám, že o ničem nevím, „přisahám, že budu vypovídat pravdu" (zde se dá nahradit slovesem slibuji, které se zdá být pro vyjádření budoucnosti vhodnější) i př́sahám, že jsem to nevědèl.

\subsection{Magické performativní formule}

Po výše uvedených úvahách vyvstává otázka úlohy performativů v historickém kontextu jazyka. Z čeho se vyvinuly a jakou měly prvotní performativy podobu se nám pravděpodobně s určitostí stanovit nepodaří, určité indicie nám však mohou již v tuto chvíli možná naznačovat, že performativy jsou záležitostí velice starou, ač třeba ne v tak široké škále dnešních významových odstínů. K abstraktním významům některých slov, která jsou dnes považována za performativy, se pravděpodobně dospívalo velmi pomalu. Byly to spíše právě konkrétní pohybové úkony, rituály, víra v nadpřirozeno, at' už bylo jakékoli podstaty, a tajemná fascinace slovem, které daly podnět k vyslovení prvních formulí, jimiž bylo „něco“ dokonáno.

Podívejme se nyní, opět z lingvisticko-historického hlediska, na několik takových „magických“ formulí, o nichž se můžeme domnívat, že jsou velice staré.

Začněme již zmíněným slovesem př́sahat, které je $\mathrm{v}$ češtině jasně a jednoznačně spjaté s úkonem rituálního sahání na něčo. Nemusí tomu tak být ve všech jazycích. Např́klad původ anglického swear pochází z germánského *swar-, objevuje se i v dalších germánských jazycích a sahá až indoevropského *swer- „ríci, mluvit" (srov. i ve slově answer „odpovídat") ${ }^{1}$. Nemohlo být „mluvit" chápáno v performativním významu ,ř́íkat posvátná slova, která nás zavážou přísahou“? Jistě se dá namítnout značná nepřesnost tohoto hypotetického explicitního performativu, který může zároveň být i konstativem, avšak nesmíme zapomínat na všudypř́tomný kontext pronesení každé výpovědi. Ostatně řekneme-li, že pachatel konečně promluvil, jistě máme na mysli, že vypovídal o svém zločinu, nikoli o jiných věcech, a zcela jistě nemáme na mysli, že by před tím neuměl mluvit. Ač nám v češtině zní mluvit ve významu ,př́sahat" podivně, neznamená to, že toto sloveso nemohlo mít v určité konkrétní situaci právě tento význam. Konec konců, v češtině sloveso mluvit, jak jsme právě viděli, může mít za určitých okolností například význam ,,prozradit“.

Dalším „magickou“ skupinou performativů by mohla být slovesa zatracovat a proklinat. $\mathrm{V}$ češtině má první souvislost se ztrátou ze světa; šlo tedy pravděpodobně o smrt, nebo spíše o přání smrti. Prokletí pak souvisí s významem „klonit se“, proklínání bylo tedy pravděpodobně spojeno s klaněním se nadpřirozeným silám (a přáním neštěstí pro nepřítele). Anglické damn pochází z latinského základu damnum „škoda“, damnare „poškozovat“; význam zatracení s poškozením bezpochyby souvisí. Jiné anglické slovo, ban ,zakazovat; proklínat“, pochází z indoevropského *bha-

${ }^{1}$ O.E. swerian "take an oath" (class VI strong verb; past tense swor, pp. sworen), from P.Gmc. *swarjanan, from root *swar- (cf. O.S. swerian, O.N. sverja, Dan. sverge, O.Fris. swera, M.Du. swaren, O.H.G. swerien, Ger. schwören, Goth. swaren "to swear"), from PIE base *swer- "to speak, say" (cf. O.C.S. svara "quarrel"). Also related to the second element in answer. 
„mluvit““. ${ }^{1}$ V románských jazycích se objevuje latinské maledicere, dosl. „mluvit špatně“, šp. maldecir, it. maledire. Opět tedy význam ,̌ŕíci“, ostatně v češtině můžeme také někoho „uřrknout“".

Naši předkové však nebyli jen zlovolní. Dokazují to např́klad slova žehnat a varovat. Žehnání bylo v některých jazycích, jak jsme již uvedli, spojeno se znamením křřže (z lat. signum „znameni“"). Samotná latina (a z ní vycházející románské jazyky) však dávala přednost prosté promluvě: benedicere ,žehnat“ doslova znamená „mluvit dobřre“. Naproti tomu v angličtině je spojeno s krví na pohanském obětním oltáři: bless „žehnat“ pochází ze starogermánského blothisojan „potřísnit krví" a blotham „krev“. ${ }^{2}$

Varovat (anglicky warn, německy warnen) pochází z indoevropského *wer„zavírat, zakrývat“. Tento kořen se vskutku v baltských a slovanských jazycích $\mathrm{v}$ tomto původním významu stále objevuje (např. česky zavírat, vrata, litevsky uzverti „zavřít“), v germánských jazycích nabývá kromě upozorňování na nebezpečí také obecné opatrnosti, obezřelosti, všímavosti. ${ }^{3}$ Významová souvislost se dá vysledovat: zakrýváme se před nebezpečím, tím se chráníme. Tím, že někoho upozorníme na nebezpečí (varujeme), tak dotyčného vlastně chráníme (zakrýváme). To, co je zakryté, je totiž chráněné.

S výčtem dalších slov bychom mohli bezpochyby pokračovat mnohem déle a zjištění by byla jistě zajímavá, není to však naším úkolem. Za základě výše uvedeného však opětovně dospíváme $\mathrm{k}$ domněnkám vyřčeným v závěru této kapitoly.

\subsection{Závěr ke druhé části}

Při hledání původních performativů jsme dospěli k následujícímu:

1) Pomocná slovesa pro vyjadřování budoucnosti již evidentně ztratila svůj původní význam. Kdysi ho však pravděpodobně v sobě nesla a to je třeba mít na zřeteli při odkrývání složité struktury současného jazyka.

2) Zdá se, že prvotní performativy byly nutně spjaty s konkrétními pohybovými úkony nebo rituály, které často zůstaly skryty v etymologii jejich dnešních slov.

3) Naši předkové si pravděpodobně záhy začali uvědomovat svou schopnost mluvit a uctívali tuto schopnost jako něco magického, co konkrétní skupinu

${ }^{1}$ O.E. bannan "to summon by proclamation," a sense surviving only in banns of marriage (1198; spelling with double $-n$ - attested from 1549), which also is partly from O.Fr. ban "public proclamation," from Frank. *ban, cognate of the O.E. word. Main modern sense of "prohibit" is from O.N. banna "curse, prohibit," and probably in part from O.Fr. ban, which also meant "outlawry, banishment." O.E., Frank. and O.N. words all are from P.Gmc. *bannan "proclaim, command, forbid" (cf. O.H.G. bannan "to command or forbit under threat of punishment," Ger. bannen "banish, expel, curse"), from PIE base *bha- "to speak" (cf. O.Ir. bann "law," from the same root). Sense evolved from "speak" to "proclaim a threat" to "curse.". Dostupné online z: http://www.etymonline.com/

${ }^{2}$ O.E. bletsian, bledsian, Northumbrian bloedsian "to consecrate, make holy," from P.Gmc. *blothisojan "mark with blood," from *blotham "blood". Originally a blood sprinkling on pagan altars. Ibid.

${ }^{3}$ O.E. warnian "to give notice of impending danger," also intrans., "to take heed," from W.Gmc. *warnojanan (cf. O.N. varna "to admonish," O.H.G. warnon "to take heed," Ger. warnen "to warn"); related to O.E. waer "aware, cautious". O.E. waer "prudent, aware, alert, wary," from P.Gmc. *waraz (cf. O.N. varr "attentive," Goth. wars "cautious," O.S. giwar, M.Du. gheware, O.H.G. giwar, Ger. gewahr "aware"), from PIE base *wer- "to cover". Ibid. 
jedinců odlišuje nejen od jedinců patřících do jiného kmene (a mluvících jiným jazykem), ale možná i jako něco, co je dáno výlučně člověku a ne jiným tvorům. (Je zcela nepochybné, že člověk v dávnověku vnímal svou sounáležitost s prírodou mnohem intenzivněji a hlouběji než dnes.) Slovo tudíž nabývalo v některých specifických kontextech a situacích magického významu. Schopnost řeči a jazyk, které jsou tak mocné a fascinující dodnes (kdyby tomu tak nebylo, nevznikly by ostatně ani žádné práce zabývající se jazykem, natož pak jeho filozofií), měly stejnou sílu i na úsvitu lidských dějin. Toto je třeba mít stále na zřeteli.

Samotné uvědomování si aktu promluvy vabstraktním smyslu, tj. existence pojmenování slova mluvit, svědčí pro velmi vyvinutou schopnost myšlení $\mathrm{v}$ abstraktní rovině.

\section{References}

AUSTIN, J. L. 2000. Jak udelat neco slovy. Praha: Filosofia. ISBN 80-7007-133-8.

BACH, K. 1975. Performatives Are Statements Too. Philosophical Studies 28, pp. 229-236. ISSN 0031-8116

BACH, K. - Harnish R. M. 1992. How Performatives Really Work: a Reply to Searle. Linguistics and Philosophy 15, pp. 93-110. ISSN 0165-0157

COHEN P. R. - LEVESQUE H. J. 1990. Performatives in a rationally based speech act theory. In: Proceedings of the 28th annual meeting on Association for Computational Linguistics, pp. 79-88. ISBN not found.

FLUSSER, V. 2005. Jazyk a skutecnost. Praha: Triáda. ISBN: 80-86138-54-2

GINET, C. 1979. Performativity. Linguistics and Philosophy 3, pp. 245-265. ISSN 0165-0157

GREWENDORF, G. 2002. How Performatives Don't Work. In: Speech Acts, Mind, and Social Reality. Springer Netherlands, pp. 25-39. ISBN 978-1-4020-0853-5

HEDENIUS, I. 1963. Performatives. Theoria 29, pp. 115-136. ISSN 0495-4548

HOLUB, J. - KOPECNY, F. 1978. Strucny etymologicky slovnik jazyka ceskeho.

Praha: SPN. ISBN 80-04-23715-0

HOLTGRAVES, T. 2005. The production and perception of implicit performatives. Journal of Pragmatics, Vol. 37, I. 12, pp. 2024-2043. ISSN 0378-2166

KOHNEN, T. 2000. Explicit performatives in Old English: A corpus-based study of directives. Journal of Historical Pragmatics, Vol. 1, N. 2, pp. 301-321. ISSN 15665852

JARY M. 2007. Are explicit performatives assertions? Linguistics and Philosophy 30, pp. 207-234. ISSN 0165-0157

JOHANSSON, I. 2003. Performatives and Antiperformatives. Linguistics and Philosophy 26, pp. 661-702. ISSN 0165-0157

MARVAN, T. 2000. Skutecnost, ktera muze byt chaosem. (Recenze). [online]: <http://www.aluze.cz/2000_03/austin.php>.

McCAUGHLEY, J. D. 1979. Remarks on the Lexicography of Performative Verbs. In: Adverbs, Vowels, and Other Objects of Wonder. Chicago and London: University of Chicago Press, pp. 161-173. ISBN 978-0226556154

ONLINE Etymology Dictionary: [online]: < http://www.etymonline.com>.

OSTLER, N. 2007. Rise slova. Praha: BB/art. ISBN 978-80-7381-152-5

RECANATI, F. 1980. Some Remarks on Explicit Performatives, Indirect Speech Acts, Locutionary Meaning and Truth-value. In: J. R. Searle - F. Kiefer - M. Bierwisch. Dordrecht, Speech Act Theory and Pragmatics. D. Reidel Publishing Company. ISBN 978-90-277-1045-1

SADOCK, J. 1974. Toward a Linguistic Theory of Speech Acts. New York: Academic Press. ISBN 978-0126143508 
SEARLE, J. R. 1989. How Performatives Work. Linguistics and Philosophy 12, pp. 535-558. ISSN 0165-0157

SWEETSER, E. E. 1990. From etymology to pragmatics. Metaphorical and cultural aspects of semantic structure. Cambridge: Cambridge University Press. ISBN 9780521424424

URMSON, J. 1977. Performative Utterances. Midwest Studies in Philosophy 2, pp. 120-127. ISSN not found.

WARNOCK, G. J. 1973. Some Types of Performative Utterance. In: I. Berlin et al., Essays on J. L. Austin. Clarendon Press, Oxford, pp. 69-89. ISBN 9780198243809

Words: 7834

Characters: 53667 (29,82 standard pages)

Dr. Zuzana Krinková, PhD

Institute of Romance Studies

Charles University in Prague

Faculty of Arts

Nám. J. Palacha 2

11638 Praha 1

Czech Republic

zuceng@gmail.com 